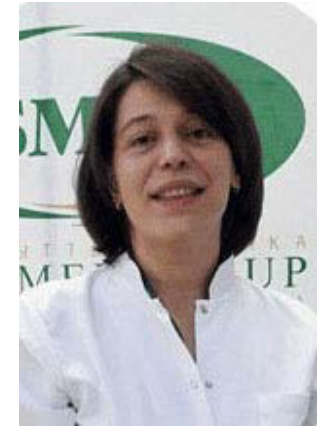

\author{
T. Shulaia ${ }^{1}$, N. Kiladze ${ }^{2}$, A. Miriamidze ${ }^{3}$ \\ ${ }^{1}$ Medical Center "Marjani" \\ ${ }^{2}$ Tbilisi State Medical University \\ ${ }^{3}$ Pathology Research Center
}

\title{
S. Spitz nevus - Clinical, Dermatoscopic and Histological Features Correlation - Cases Report
}

Introduction. S. Spitz nevus is a benign melanocytic neoplasm composed from spindled or epitheloid new melanocytes mostly appearing in the pediatric age and described previously as juvenile melanoma. In accordance with the literature, the majority of cases are observed in the first two decades of life mainly in fair-skinned persons representing about $1.0 \%$ of all childhood melanocytic nevi. The S. Spitz nevus was first described in 1948 by Sophie Spitz as benign juvenile melanoma with good prognosis but histological resemblance with melanoma and bears her name [8]. It may mimic melanoma at clinical, dermatoscopic and histopathological levels being today the subject of discussion and one of the most difficult questions among the pigmented lesions both for dermatologists and morphologists. As a result, there are contradictions regarding the appropriate therapy and prognosis.

The aim of the study. To describe the correlations between the clinical,dermatoscopic and pathomorphological features of S. Spitz nevi in three clinical cases.

Materials and methods. The content analysis, bibliosemantic method of studying the actual scientific researches concerning non-invasive methods of S. Spitz nevus evaluation was used. The study was carried out in the following scientific databases: PubMed-NCBI, Medline, Cochranel Library, EMBASE, ReseachGate by keywords: S. Spitz nevi, dermatoscopy, correlation with morphological examination. Digital dermatoscopic images were captured using Dermatoscope (DermLite DL3) mounted on the digital camera Galaxy S-4 Samsung Corporation) using the ultrasound gel for imersion dermatoscopy. All images were evaluated in accordance with algorithm of $\mathrm{H}$. Kittler.

Results and discussion. Dermatoscopy is the appropriate and helpful method for diagnosing S. Spitz nevus, but together with this the histopathological and immunohistochemical examinations are still needed to rule out malignancy, especially for uncommon or atypical dermatoscopic patterns.

S. Spitz nevus clinically is presented as a solitary, pink, red or brown papule most commonly located on the face or extremities and characterized by an initially rapid growth. The other clinical characteristic feature is size, thus they are usually less than $1.0 \mathrm{~cm}$ in diameter, larger size is considered as abnormal. They may be pigmented when colours ranging from tan to dark brown or even black, but typically they are from pink to red because of limited melanin content and increased vascularity.

Clinically the most often features are symmetry, smooth, dome-shaped and hairless surface, and well-demarcated borders. Both genders are equally affected. However, because of few specific clinical features, it is often difficult to make a correct diagnosis of S. Spitz nevus with only eyes, sometimes it is clinically mistaken with other skin tumors such as hemangioma, verruca vulgaris, dermatofibroma, etc. Dermatoscopy became very helpful in S. Spitz nevus diagnosis accuracy and its most typical variants determining and thus does not generally pose any problems of interpretation, especially in the pediatric age [2]. On the other hand, the diagnosis of atypical forms is more complicated, due to the morphologic overlap with atypical S. Spitz tumor and spitzoid melanoma [5]. Dermatoscopic features of these varieties were described in a few studies $[1,7]$ and attempt to offer a modern classification on dermatoscopy of S. Spitz nevi was done in the works of A. Lallas et al. [6].

Histopathologically, the S. Spitz nevus may be classified as functional, intradermal in the majority of cases, compound. Histopathologically, S. Spitz nevus is neoplastic proliferation of melanocytes with large nuclei, prominent nucleoli, and abundant ground-glass cytoplasm, arranged in nests. Nests are equally sized, shaped, and spaced at the junction, arranged perpendicular and parallel to the skin surface [4]. Melanin pigment is common within spindle cells and dermal melanophages.

The management of S. Spitz nevus is still controversial. Age is one of the most important factors because the incidence of malignant melanoma increases with age. According to dermatoscopic morphology of S. Spitz nevi and management guidelines by 2017 British Association of Dermatologists [6], surgical excision should be reserved for suspicious lesions in children at 12 years of age and 
older and for all suspicious neoplasm with an atypical pattern when malignant melanoma cannot be excluded in children of all ages. Clinical and dermatoscopic followup should be continued until these neoplasms maintain the typical features of common nevi or disappear [7].

Descriptions of clinical cases: in this report we discuss 3 different cases of S. Spitz nevi. The patients were at the age of 7 to 11 years old, had unremarkable medical histories and rapid growth of elements in the last period.

Case 1: a 7-year-old boy with skin phototype 2, presented with an elevated firm reddish- brown papule, $4.0 \mathrm{~mm}$ in diameter, located on the dorsal surface of the left ankle with a hyperkeratosis surface. One year ago, the lesion had started as a $2.0 \mathrm{~mm}$ flat brown lesion and 2 months ago the lesion had increased rapidly in extension and became a $4.0 \mathrm{~mm}$ structure. The boy was otherwise healthy, with no history of trauma and sunburn. His medical history was unremarkable and no such lesions had been found in other family members. The digital dermatoscopy examination was provided and S. Spitz nevus was diagnosed. The lesion was excised for histopathologic examination.

Dermatoscopic picture: pattern of brown globules located symmetrically on the periphery and reddish or skin-color structureless areas in the center are best interpreted as a S. Spitz nevus, peripheral clods/globules indicated horizontal growth of the lesion (figure 1).
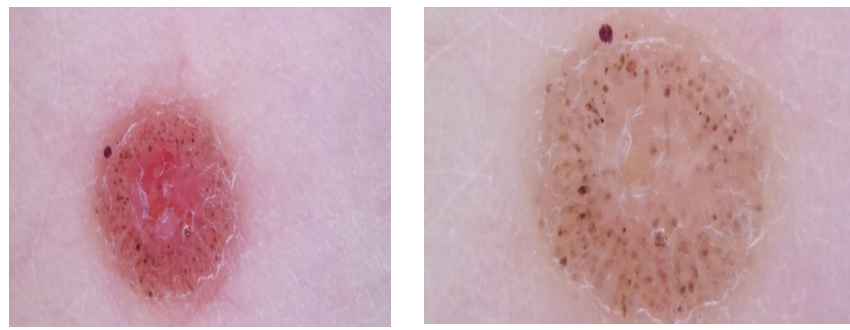

Figure 1. Dermoscopy, magnification 30x

Histomorphological result: epidermis, dermis and subcutaneous tissue of the samples were studied. Epidermal hyperplasia, hypergranulosis and hyperkeratosis were observed. Epidermal melanocytes were arranged in nests, nests of melanocytes within the epidermis were elongated and vertically oriented. There were clefts between the nests of melanocytes and keratinocytes. Melanocytic nests were discrete and cohesive. Nests of melanocytes predominated over solitary melanocytes; melanin incontinence was seen in some sites. Melanocytes became smaller in deeper layers; also there were no mytotic figures and ulceration (figure 2).
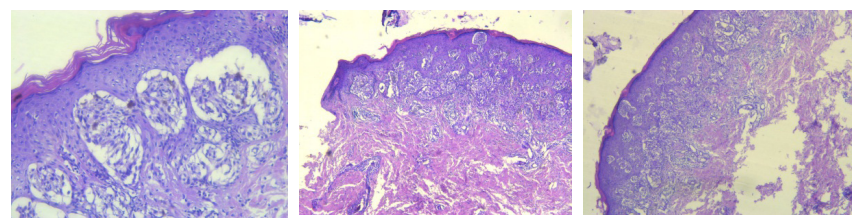

Figure 2. Histopathology: nests of fusiform cells in the epidermal base and in the dermis. Nests of melanocytes within the epidermis are elongated and vertically oriented
Dermatoscopic/dermatopathologic correlation: brown clods located on the periphery of the element corresponded to accumulations of melanin in melanocytes in the epidermaldermal junction.

Case 2: 7-year-old boy with skin phototype 2, presented with a dark gray-blue semicircular nodule of $8.0-8.0 \mathrm{~mm}$ in diameter located at the base of the left thumb. His mother first noticed its appearance at the age of 2-3 years, since then it has been "undulating", but constantly increasing. Over the past 2 months the size of the element has increased dramatically and it has risen above the skin level and solid with palpation (figure 3).

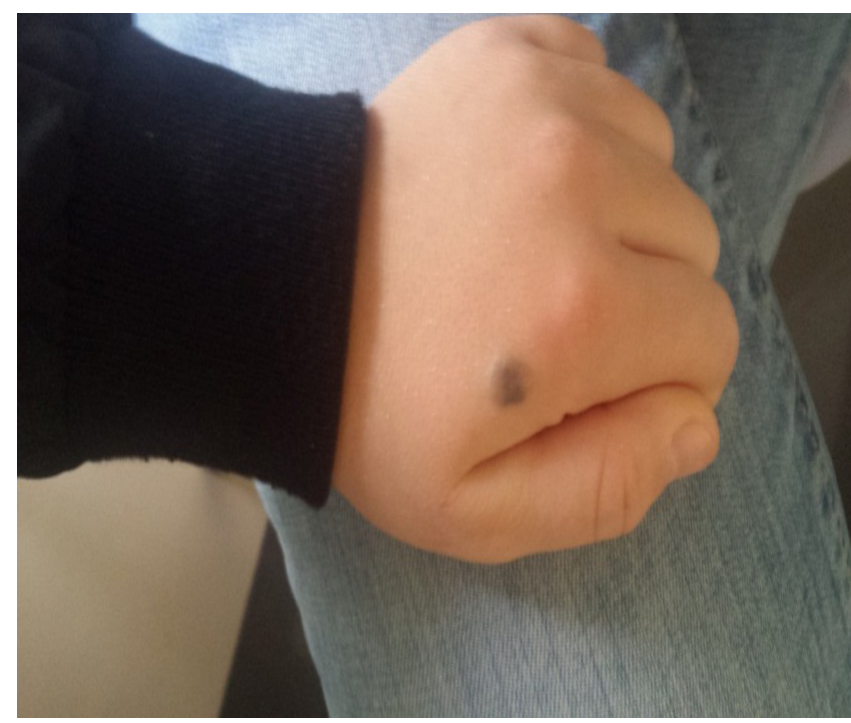

Figure 3. Clinical appearance. Hyperchromic nodule of $8 \mathrm{~mm}$ in diameter

Dermatoscopic picture: the pattern of polarising-specific white-grey reticular lines well visible in the central part and black stuctureless area; since white lines are clues to melanoma, the lesion needs to be excised to exclude that possibility (figure 4).

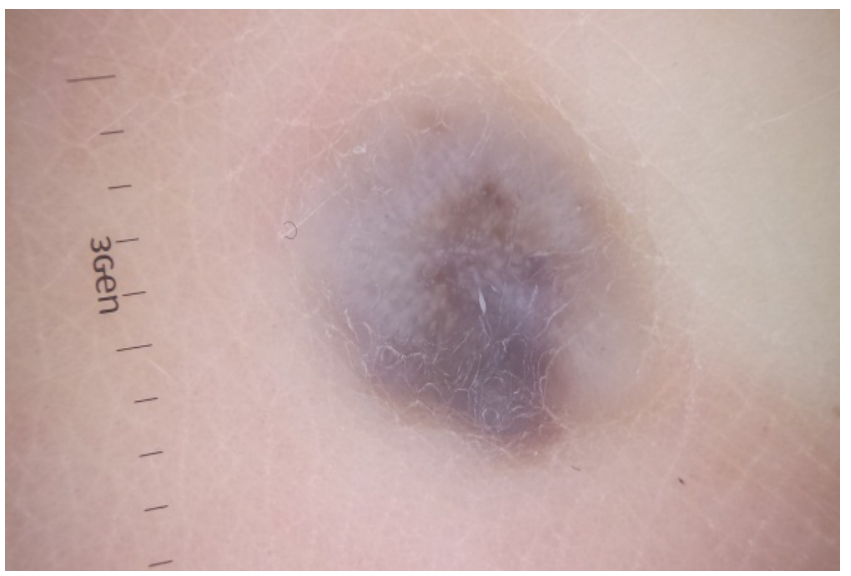

Figure 4. Dermoscopy, magnification 30x

Histomorphological examination: the material studied is epidermis, dermis and subcutaneous tissue. At the dermo-epidermal junction and in the dermis itself, there were elongated ("spindle") and round-shaped ("epithelioid") cells with budlike and solid-trabecular structures. In the 
nuclei of some cells the prominent nucleoli, and focally, figures of mitosis were found. There were no evidence of proliferation in the epidermis of these cells. However, there is a picture of distribution in subcutaneous tissue (figure 5).

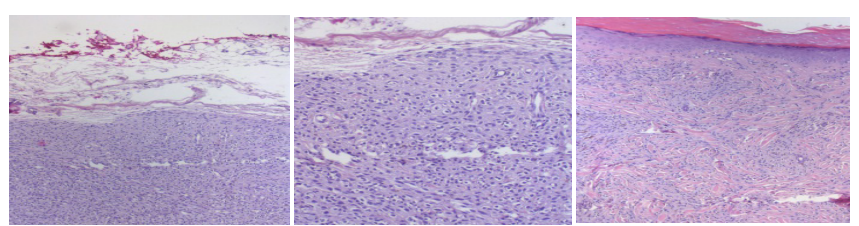

Figure 5. Histopathology. presence of elongated ("spindle") and round-shaped ("epithelioid") cells with budlike and solidtrabecular structures. In the nuclei of a part of the cells, we find nuclei, and focally, mitosis figures

Immunohistochemical staining results of the lesion: the majority of epithelioid cells were HMB-45-positive and Ki67 positive $<5.0 \%$ of cells (figures 6,7 ).

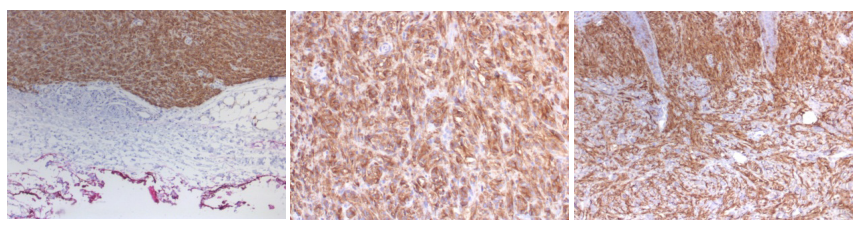

Figure 6. Immunohistochemical Analysis HMB 45

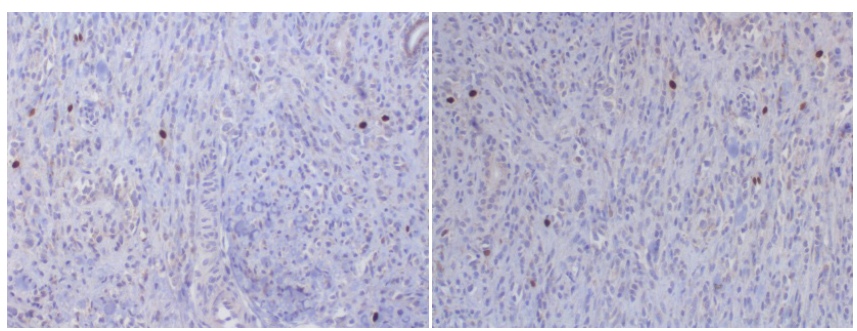

Figure 7. Immunohistochemical Analysis Ki67 <5.0\%

Dermatoscopic/dermatopathologic correlation: white-grey lines that were seen under polarized dermoscopy, could be seen in scars, dermatofibromas, basal cell carcinomas, and also in melanomas and S. Spitz nevi. These structures correlate histopathologically with altered collagen in the dermis (fibrosis). The brief ringent properties of collagen bundles cause rapid randomization of polarized light. This is the reason collagen appears bright white and more conspicuous under polarized dermoscopy [9]. The dark, structureless region corresponds to melaninfilled melanocytes.

Case 3: 11-year-old girl with skin phototype 2, presented with a redish-brown semicircular nodule of 7.0-7.0 $\mathrm{mm}$ in diameter at the tip of the nose. Mother first noticed its appearance at the age of 6-7 years, since then the node has constantly increased in size. During the last 2 years it increased rapidly in extension and became elevated above the skin. At the first examination, the biopsy was proposed to confirm the diagnosis, which the parents refused. Follow-up examinations were performed every 3 and 6 months.
Dermatoscopic picture: a pigmented reticular pattern recognized during the initial examination. Based on our observation no changes has been found, only the size was enlarged. Over time the lesion became stable thus showing the homogeneous pattern. The progressive decrease of pigmentation or the complete involution of the lesion could be the last evolution stage (figures 8-12).

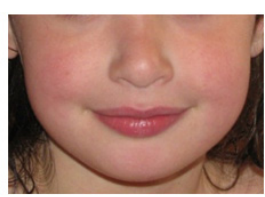

2013

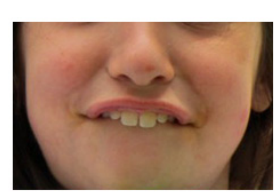

2015

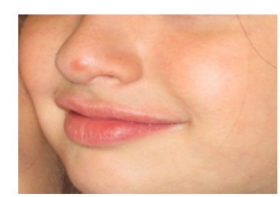

2017
Figure 8. Previous photos brought by parents
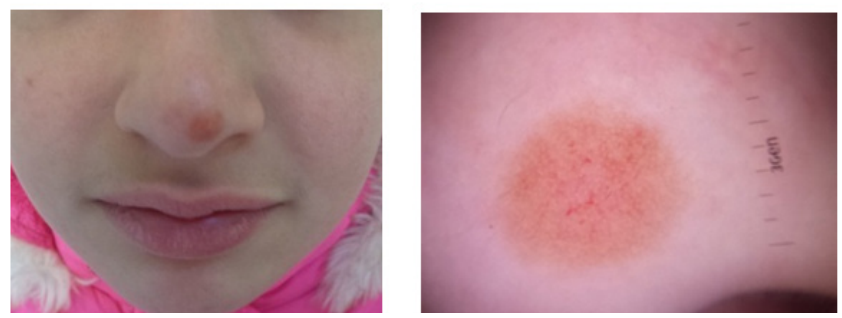

Figure 9. Clinical and dermatoscopy images 04.2018 . Initial examination

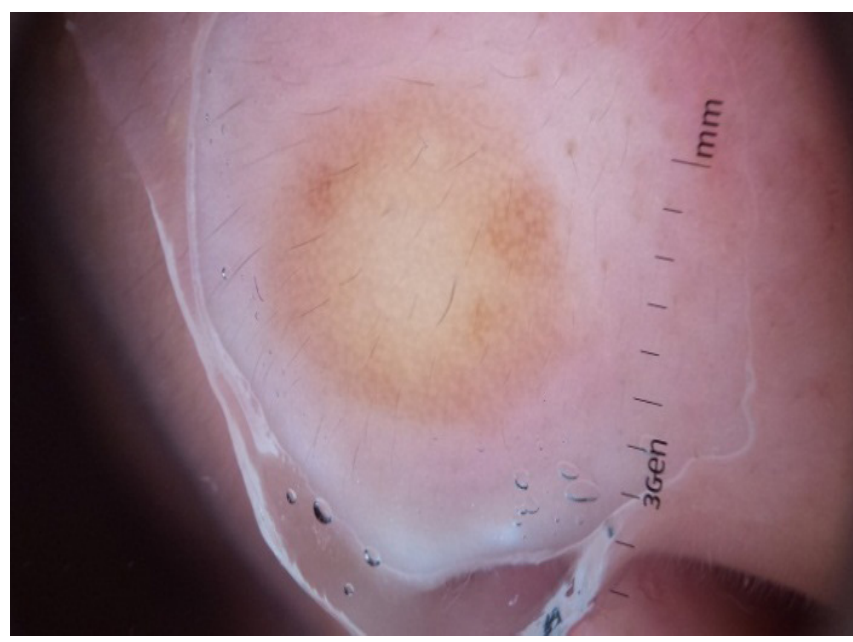

Figure 10. Dermatoscopy 09.2018

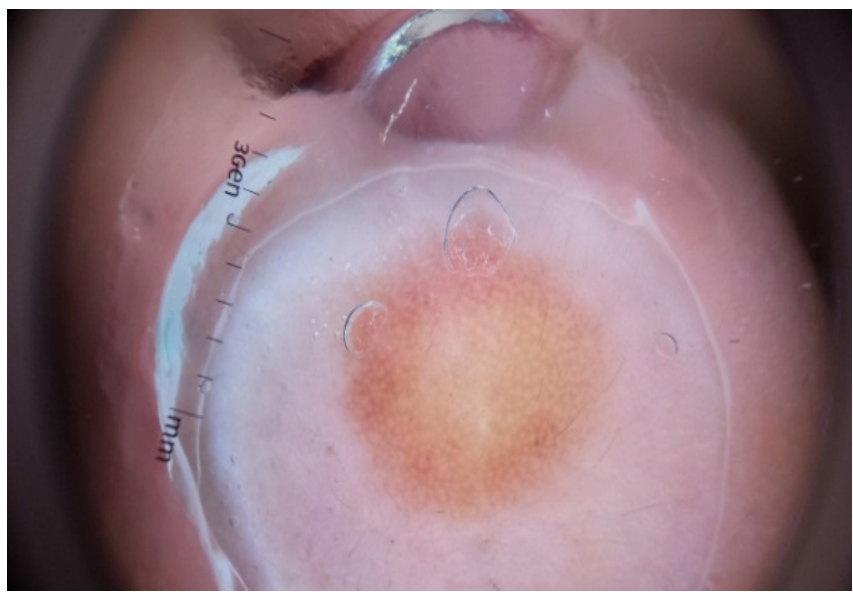

Figure 11. Dermatoscopy 12.2018 

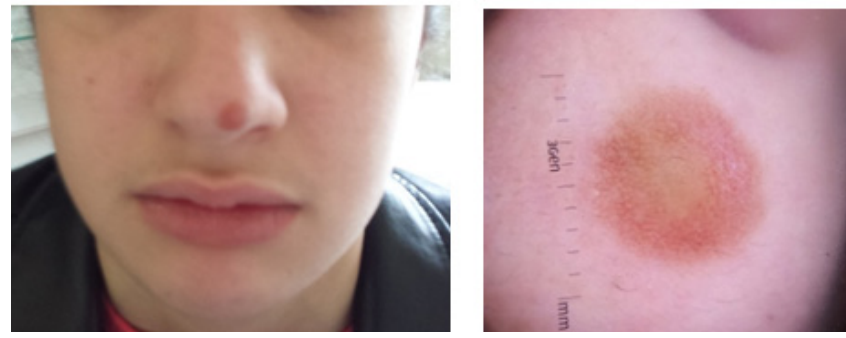

Figure 12. Clinical and dermatoscopy images 04.2019
Conclusions. There are many contradictions in the diagnosis and management of S. Spitz nevus due to its peculiar clinical, dermatoscopic and histomorphological features. Dermatoscopy has emerged as an important tool in the evaluation of patients with such lesions, but it is still necessary to perform a biopsy or excision for cases with suspicious clinical manifestations or atypical dermatoscopic patterns. As well the short-term follow-up is helpful and should be continued until these neoplasms maintain the typical features of common nevi or disappear.

\section{References}

1. Argenziano G, Scalvenzi M, Brunetti B et al. Dermatoscopic pitfalls in differentiating pigmented Spitz naevi from cutaneous melanomas. Br J Dermatol. 1999;141(5):788-793. https://doi.org/10.1046/j.1365-2133.1999.03150.x

2. Argenziano G, Soyer HP, Ferrara G et al. Superficial black network: an additional dermoscopic clue for the diagnisis of spindle and/or epithelioid cell nevus. Dermatology 2001;203:333-335. https://doi.org/10.1159/000051784

3. Emiroglu N, Y1ldız P, Biyik OD et al. Evolution of Spitz nevi. PediatrDermatol 2017;34(4):438-445. https://doi. org/10.1111/pde. 13184

4. Dal Pozzo V, Benelli C, Restano L. Clinical review of 247 case records of Spitz Nevus (epitheliod cell and/or spindle cell nevus). Dermatology. 1997;194:20-25. https://doi.org/10.1159/000246051

5. Ferrara G, Cavicchini S, Corradin MT. Hypopigmented atypical spitzoid neoplasms (atypical Spitz nevi, atypical Spitz tumors, spitzoid melanoma): a clinicopathological update. Dermatol Pract Concept. 2015;5(1):45-52. https://doi. org/10.5826/dpc.050106

6. Lallas A, Apalla Z, Ioannides D et al. Update on dermoscopy of Spitz/Reed naevi and management guidelines by the International Dermoscopy Society. Br J Dermatol 2017;177(3):645-655. https://doi.org/10.1111/bjd.15339

7. Moscarella E, Lallas A, Kyrgidis A. Clinical and dermoscopic features of atypical Spitz tumors: a multicenter, retrospective, case-control study. J Am Acad Dermatol. 2015;73(5):777-784. https://doi.org/10.1016/j.jaad.2015.08.018

8. Spitz S. Melanomas of childhood. Am J Pathol. 1948;24:591-609.

9. Verzi AE, Quan VL, Walton KE, Martini MC, Marghoob AA, Garfield EM et al. The diagnostic value and histologic correlate of distinct patterns of shiny white streaks for the diagnosis of melanoma: A retrospective, case-control study. J Am Acad Dermatol. 2018;78:913-919. https://doi.org/10.1016/j.jaad.2017.11.021

Стаття надійшла до редакції журналу 28.01.2020 р.

Conflict of interest

The authors of this article argue that there is no conflict of interest.

\section{Невус С. Шпітц - клінічні й дерматоскопічні особливості та кореляція з патоморфологічними показниками - клінічні випадки}

\section{Т. Шулаіа, Н. Кіладзе, А. Міріамідзе}

Вступ. Невус С. Шпітц - доброякісний меланоцитарний новоутвір, що складається 3 веретеноподібних або епітелоїдних неомеланоцитів. Здебільшого з'являється в дитячому віці й раніше був описаний як ювенільна меланома. Відповідно до інформації, отриманої з сучасних джерел, більшість випадків виявляється у перші два десятиліття життя, переважно у світлошкірих людей, становить близько 1,0 \% усіх меланоцитарних невусів дитячого віку. Невус С. Шпітц уперше був описаний у 1948 р. Софі Шпітц як доброякісна ювенільна меланома зі сприятливим прогнозом, але гістологічною подібністю з меланомою. Невус С. Шпітц може імітувати меланому на клінічному, дерматоскопічному та гістопатологічному рівнях, що й досі є предметом обговорення та одним із найскладніших питань серед пігментованих уражень як для дерматологів, так і для морфологів, із огляду на численні суперечності щодо лікування та прогнозу.

Мета. Описати кореляцію між клінічними, дерматоскопічними та патоморфологічними особливостями невусів С. Шпітц у трьох клінічних випадках. 
Матеріали й методи. Використано контент-аналіз, бібліосемантичний метод вивчення актуальних наукових досліджень стосовно невусу С. Шпітц. Пошук джерел здійснено в наукометричних медичних базах інформації: PubMed-NCBI, Medline, Cochranel Library, EMBASE, ReseachGate за ключовими словами: невус С. Шпітц, дерматоскопія, кореляція з патоморфологічними показниками. Описано три клінічні випадки. Для цифрової дерматоскопії використано дерматоскоп DermLite DL3 із вмонтованою цифровою камерою Galaxy S-4 Samsung Corporation, для імерсійної дерматоскопії - гель для ультразвукового дослідження. Всі отримані зображення оцінені згідно з алгоритмом Х. Кіттлера.

Результати. Дерматоскопія $є$ актуальним і корисним методом діагностики невусу С. Шпітц, хоча разом 3 нею потрібно проводити гістопатологічні та імуногістохімічні дослідження для виключення злоякісності, особливо у випадках їх незвичайної або атипової дерматоскопічної структури.

Невус С. Шпітц клінічно представлений у вигляді одиночної рожевої, червоної або коричневої папули, найчастіше на обличчі або кінцівках, що спочатку характеризується швидкими темпами росту. Іншою характерною клінічною ознакою $є$ розмір. Зазвичай вони менші ніж 1,0 см у діаметрі, більший розмір вважається нетиповим. Можуть пігментуватися, набуваючи відтінків від засмаги до темно-коричневого або навіть чорного, але зазвичай - від рожевого до червоного, що пов'язується з невеликим умістом меланіну та посиленою васкуляризацією. Клінічно найчастіше ознаками є симетрія, гладка, куполоподібна та безволоса поверхня, а також добре окреслені межі. Відмінностей за статевою приналежністю немає. Однак через нечисленні специфічні клінічні особливості часто тяжко поставити правильний діагноз невусу С. Шпітц неозброєним оком, ототожнюючи його з іншими пухлинами шкіри, такими як гемангіома, бородавка, дерматофіброма. Дерматоскопія дуже помічна для точної діагностики невусу С. Шпітц та його найбільш типових варіантів. Проте тактика ведення таких хворих суперечлива. Відповідно до їх дерматоскопічної морфології та керівних принципів Британської асоціації дерматологів 2017 р. хірургічне висічення слід проводити у випадках підозрілих уражень у дітей віком від 12 років і старших, а також усіх підозрілих атипових новоутворів, якщо неможливо виключити наявність злоякісної меланоми, у дітей будь-якого віку. Здійснено опис і обговорення трьох різних випадків невусів С. Шпітц. Хворі віком від 7 до 11 років мали необтяжений анамнез і швидкий темп росту утворів за останній період.

Висновки. У діагностиці та лікуванні невусу С. Шпітц існує багато суперечностей із огляду на особливість його специфічних клінічних, дерматоскопічних та гістоморфологічних показників. Дерматоскопія стала важливим інструментом для оцінки таких уражень, хоча у всіх випадках утворень із підозрілими клінічними проявами або атиповими дерматоскопічними ознаками все ж потрібно проводити біопсію або висічення утвору. Окрім цього, важливим $є$ короткотривале спостереження за хворими, яке слід продовжувати, допоки ці новоутвори не набудуть типових ознак звичайних невусів або не зникнуть.

Ключові слова: невус С. Шпітц, дерматоскопія, гістоморфологічне дослідження.

\title{
S. Spitz Nevus - Clinical-Dermatoscopic and Histological Features Correlation - Cases Report
}

\author{
T. Shulaia, N. Kiladze, A. Miriamidze
}

Introduction. S. Spitz nevus is a benign melanocytic neoplasm composed from spindled or epitheloid new melanocytes mostly appearing in the pediatric age and described previously as juvenile melanoma. In accordance with the literature the majority of cases are observed in the first two decades of life mainly in fair-skinned persons representing about $1.0 \%$ of all childhood melanocytic nevi. The S. Spitz nevus was first described in 1948 by Sophie Spitz as benign juvenile melanoma with good prognosis but histological resemblance with melanoma and bears her name. It may mimic melanoma at clinical, dermatoscopic and histopathological levels being today the subject of discussion and one of the most difficult questions among the pigmented lesions both for dermatologists and morphologists. As a result, there are contradictions regarding the appropriate therapy and prognosis.

The aim of the study. To describe the correlations between the clinical, dermatoscopic and pathomorphological features of S. Spitz nevi in three clinical cases.

Materials and methods. The content analysis, bibliosemantic method of studying the actual scientific researches concerning non-invasive methods of S. Spitz nevus evaluation were used. The study was carried out in the following scientific databases: PubMed-NCBI, Medline, Cochranel Library, EMBASE, ReseachGate by keywords: S. Spitz nevus, dermatoscopy, correlation with morphological examination. Three clinical cases were described. Digital dermatoscopic images were captured using Dermatoscope (DermLite DL3) mounted on the digital camera Galaxy S-4 Samsung Corporation) using the ultrasound gel for imersion dermatoscopy. All images were evaluated in accordance with algorithm of $\mathrm{H}$. Kittler. 
Results. Dermatoscopy is the appropriate and helpful method for diagnosing S. Spitz nevus, but together with this the histopathological and immunohistochemical examinations are still needed to rule out malignancy, especially for uncommon or atypical dermatoscopic patterns. S. Spitz nevus clinically is presented as a solitary, pink, red or brown papule most commonly located on the face or extremities and characterized by an initially rapid growth. The other clinical characteristic feature is size, thus they are usually less than $1.0 \mathrm{~cm}$ in diameter, larger size is considered as abnormal. They may be pigmented when colours ranging from tan to dark brown or even black, but typically they are from pink to red because of limited melanin content and increased vascularity. Clinically the most often features are symmetry, smooth, dome-shaped and hairless surface, and well-demarcated borders. Both genders are equally affected. However, because of few specific clinical features, it is often difficult to make a correct diagnosis of S. Spitz nevus with naked eyes, sometimes it is clinically mistaken with other skin tumors such as hemangioma, verruca vulgaris, dermatofibroma, etc. Dermatoscopy became very helpful in S. Spitz nevus diagnosis accuracy and its most typical variants determining. The management of S. Spitz nevus is still controversial. According to dermatoscopic morphology of S. Spitz nevi and management guidelines by 2017 British Association of Dermatologists, surgical excision should be reserved for suspicious lesions in children at 12 years of age and older and for all suspicious neoplasm with an atypical pattern when malignant melanoma cannot be excluded in children of all ages. Clinical and dermatoscopic follow-up should be continued until these neoplasms maintain the typical features of common nevi or disappear. In this report we discuss 3 different cases of S. Spitz nevi. The patients were at the age of 7 to 11 years old, had unremarkable medical histories and rapid growth of elements in the last period.

Conclusions. There are many contradictions in the diagnosis and management of S. Spitz nevus due to its peculiar clinical, dermatoscopic and histomorphological features. Dermatoscopy has emerged as an important tool in the evaluation of patients with such lesions, but it is still necessary to perform a biopsy or excision for cases with suspicious clinical manifestations or atypical dermatoscopic patterns. As well the short-term follow-up is helpful and should be continued until these neoplasms maintain the typical features of common nevi or disappear.

Keywords: S. Spitz nevus, dermatoscopy, histomorphological examination.

\section{Information about the authors}

1. Teona Shulaia, MD, Medical center "Marjani", physician, (3 Ateni str., 0179, Tbilisi, Georgia; 4 Kipshidze str. 0179 , Tbilisi, Georgia, phone + (955) 5991032 31; e-mail: t_shulaia@yahoo.com)

2. Natalia Kiladze, MD PhD, Tbilisi State Medical University, Department of Dermato-Venerogy, professor (33 Vazha Pshavela Ave, 0169, Tbilisi, Georgia; 62 I.Chavchavadze Ave, 0179, Tbilisi, Georgia, phone +(995) 599242056 , e-mail: natakiladze@yahoo.com)

3. Armaz Miriamidze, MD, PhD, Medical Center "Pathology Research Center", 5 Lubliana str, 0159, Tbilisi, Georgia, +(995 32) 2475960; 37 Iv. Javakhishvili str., phone +(995) 591273090, e-mail: armazi1@yahoo.com) 